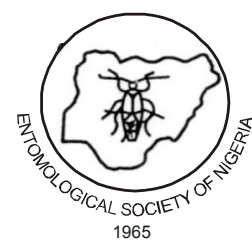

\title{
Biological Efficacy of Two Plant Powders as Mothcidal Agents Against Sitotroga cerealella (Olivier, 1789) (Lepidoptera: Gelechiidae) Infesting Paddy Rice
}

\author{
Oyeniyi, E. A. \\ Department of Biology, Federal University of Technology \\ P. M. B. 704, Akure, Ondo State, Nigeria
}

\begin{abstract}
This study investigated the mothcidal efficacy of powders of Alstonia boonei (De wild) stem bark and Acalypha godseffienna (Muell Arg.) leaf at ambient temperature $\left(28 \pm 3^{\circ} \mathrm{C}\right)$ and relative humidity $(75 \pm 6 \%)$ against adult Sitotrog a cerealella infesting paddy rice. Adult Sitotroga cerealella were exposed to both botanical powders using contact toxicity test at $1-5 \mathrm{~g} / 20 \mathrm{~g}$ of paddy rice and mortality was assessed after $24,48,72$ and 96 hours post-treatment respectively. The control experiment was also set-up for each botanical. Generally, both botanical powders significantly $(\mathrm{p}<0.05)$ evoked higher moth mortality when compared to control. But, none of both plant powders elicit complete moth mortality $(100 \%)$ at all the experimental dosage and exposure time. Lower dosage of $A$. boone $i$ was however required to achieve $50 \%$ (24 hours: $0.672 ; 72$ hours: 0.006 ) mortality in $S$. cerealella when compared to that of $A$. godseffienna (24 hours: $1.546 ; 72$ hours: 0.238 ). Also, $A$. boone $i$ at all experimental dosage significantly reduced $(\mathrm{p}<0.05)$ emergence of $S$. cerealella when compared to control while $A$. godseffiana applied only at $2-5 \mathrm{~g} / 20 \mathrm{~g}$ of paddy rice significantly reduced $(\mathrm{P}<0.05)$ adult emergence when compared to control. The effect of $A$. boone $i$ on the percentage inhibition rate of S. cerealella was significant $\left(\mathrm{F}_{4,15}=6.69 ; \mathrm{P}=0.003\right)$ while that of $A$. godseffiana was not significant $\left(\mathrm{F}_{4,15}=1.65 ; \mathrm{P}=\right.$ 0.213 ). It could therefore be concluded that powders of both botanicals could help in the management of $S$. cerealella infesting rice grains in Nigeria.
\end{abstract}

Keywords: Alstonia boonei, Acalypha godseffienna, Inhibition rate, Mothcidal, Sitotroga cerealella.

\section{INTRODUCTION}

In most developing countries of the world, particularly Africa, food security remained one of the best ways to attain national peace, prosperity and better living standard among the citizenry. It has however remained a mirage as several citizens still suffer from malnutrition.

*Correspondence email: oyemmayo@gmail.com, oyeniyi@futa.edu.ng

Tel: +2347030243167
This has prompted the government of most African countries to continually import food crops to augment the little being produced indigenously (Vaughan, 2014; Oladimeji, 2017). Agriculture is generally agreed to be the main corner stone to uphold the economy of most developing countries. Consequently, past years has witnessed an increased food production aimed at meeting the local food production (Gbaye et al, 2015). For instance, rice production in Nigeria increased from 3.5 
million tonnes in year 2012 to 5.8 million tonnes in year 2017 (Gbaye et al., 2015; Goronyo, 2017). Nonetheless, the country still struggles to produce enough food to feed a teeming population of over 170 million people. Apart from this, local food production in Nigeria still suffers from poor and inadequate storage facilities which have subjected most food crops to insect pest attack (Gbaye et al., 2015).

Oryza sativa (L.) commonly known as rice is one of the major food crops suffering from insect pest attack due to poor processing techniques. Losses of rice grains ranging from 10 to $20 \%$ of overall production has been linked to various insect pest like Rhyzopertha dominica (Fabricius), Sitotroga cerealella (Olivier), Sitophilus oryzae (Linnaeus) and Sitophilus zeamais (Motschulsky) among others (Philips and Throne, 2010; Togola et al., 2013; Gbaye et al., 2015; Akinneye and Oyeniyi, 2016). Of all the pest infesting paddy rice, $S$. cerealella remained the most destructive as both the adults and larva stages are capable of causing havoc (Akinneye and Oyeniyi, 2016). In fact, the multivoltine nature of reproduction and high flight activity of the adult stage coupled with the ability of the larva stage to devour wholesome grain kernels makes this insect a notorious pest of paddy rice. Thus, infestations by $S$. cerealella have resulted in indirect economic loss through pest control costs, quality losses and consumer complaints. In an effort aimed at tackling the various menace associated with infestation of $S$. cerealella, insecticides have remained the cornerstone in their management. Synthetic insecticides have however been given priority over the use of biopesticides, especially in large scale control. But, various problems associated with their usage continued to frustrate their continuous acceptance in most part of the world. Against this backdrop, researchers are now shifting their attention to botanical insecticides that are believed to possess reduced risk criteria and thus pose little or no threat to the people and the environment. Plant-based insecticides therefore have a critical role to play in the production and post-harvest protection of food crops like rice in a developing country like Nigeria.

Alstonia boonei (De wild) and Acalypha godseffienna (Muell) are two botanicals that are chiefly available in rain forest zones of Nigeria. A. boonei (cheesewood) is a large deciduous, tropical-forest tree belonging to the dogbane family, Apocynaceae while $A$. godseffienna (copper leaf) is a very colourful tropical shrub belonging to family Euphorbiaceae (Ogundaini, 2005; Adotey et al., 2012). The mothcidal efficacy of the powder of the stem bark and leaves of $A$. boonei and $A$. godseffienna, respectively against $S$. cerealella remained to be investigated. Crude powders are believed to contain several phytochemicals working synergistically to augment their toxicity against insect pest (Jenson et al., 2006; Akinkurolere, 2007). Thus, the protective properties of both botanical powders against $S$. cerealella infesting rice grains in Nigeria were fully investigated in this study.

\section{MATERIALS AND METHODS}

\section{Experimental Location}

The experiment was carried out from February 2016 to August 2016, at the Storage Entomology Research Laboratory of Biology Department, Federal University of Technology Akure, Ondo State, Nigeria.

\section{Insect Culture}

Adults $S$. cerealella used in this study were obtained from infested paddy rice sourced from Ondo State Agricultural Development Program, Ondo road, Akure, Nigeria. Clean FARO-47 
paddy rice variety was also obtained from ADP, Akure, Nigeria and disinfested in the freezer at $-10^{\circ} \mathrm{C}$ for two weeks. The disinfested paddy rice grains were then allowed to equilibrate in the laboratory for three days. The moths were reared on the paddy rice variety inside 1.5 litres plastic containers. The containers were covered with perforated lid and muslin cloth to prevent the escape of insects and to allow air into them. The moths were collected into the containers by the use of an aspirator, and they were reared for two generations on FARO-47 paddy rice variety to eliminate the effect of parent food selection before being used for bioassay test. The plastic containers used for the insect rearing were kept inside breeding cage at ambient temperature $\left(28 \pm 3^{\circ} \mathrm{C}\right)$ and relative humidity (75 $\pm 6 \%)$.

\section{Preparation of the Plant Powders}

The leaves of $A$. godseffiena and $A$. boonei were obtained from Obanla, beside Centre for Continuing Education (CCE), Federal University of Technology, Akure, Nigeria. The bark of $A$. boonei was obtained from the Ologbo sawmill at Road block, Akure, Nigeria. The leaves and the stem bark were air dried separately for seven days in the laboratory and ground to powder using electric blender (RHA Mumbai - 400 078/India). The ground powders were separately sieved to pass through $180 \mu$ sieve to obtain fine powders. The powders were thereafter placed in two air-tight plastic containers and labelled accordingly prior to use.

\section{Contact Toxicity}

Twenty grams of paddy rice (FARO-47) seeds were weighed using Metler Beam PB 3002 weighing balance and thoroughly mixed with 1, 2, 3, 4 and $5 \mathrm{~g}$ of $A$. boonei stem bark and $A$. godseffiena leaf powders in $280 \mathrm{ml}$ plastic containers. Control treatment $(0.0 \mathrm{~g})$ (control), set along with the other treatments. The powders and paddy rice seeds were thoroughly mixed together using glass rod to ensure uniform coating of paddy rice with the powders. Five pairs of adult moths were introduced into each plastic container and covered. Each treatment was replicated four times and adult mortality was recorded after 24, 48, 72 and 96 hours post-treatment. Both dead and live insects were removed on the fifth day and containers of the experiments were left for 28 days counting from the date of infestation to allow for adult emergence; thereafter, the number of emerged adults was counted. Inhibition rate (\%IR) in adult emergence was calculated using the method described by Tapondju et al (2002).

$$
\% \mathrm{IR}=\frac{C_{n}-T_{n}}{C_{n}} \times \frac{100}{1}
$$

Where $\mathrm{C}_{\mathrm{n}}$ is the number of insects that emerged in the control treatment

$\mathrm{T}_{\mathrm{n}}$ is the number of adult insects that emerged in the treated grains.

The experiment was set-up in a complete randomized block design

\section{Data Analysis}

Abbott (1925) formula was used to correct data on adult mortality counts using control mortality. All data were later subjected to oneway analysis of variance at $p<0.05$ and means were separated using Tukey's Test. Data on adult mortality were also subjected to Probit analysis to determine the dosage of $A$. boonei and $A$. godseffiana needed to achieve $50 \%$ and $95 \%$ mortality in S. cerealella (Finney, 1971).

\section{RESULTS}

Effect of powders of Alstonia boonei stem bark and Acalypha godseffienna leaf part on the mortality of adult Sitotroga cerealella

Table 1 and 2 show the percentage mortality of adult $S$. cerealella exposed to powder of $A$. boonei and $A$. godseffienna respectively. 
Mortality of adult moth increased with increasing dosage of both botanicals and exposure time. Similarly, both botanicals significantly evoked $(p<0.05)$ higher moth mortality when compared to control. However, none of both plant powders elicit complete moth mortality $(100 \%)$, even at the highest experimental dosage and exposure time. Also, no significant difference $(p>0.05)$ existed in the mortality of moths exposed to all the experimental concentrations of $A$. boone $i$ after 48, 72 and 96 hours respectively (Table 1). On the contrary, mortality values of moths exposed to the highest experimental dosage $(5.0 \mathrm{~g} / 20 \mathrm{~g}$ of paddy rice) of $A$. godseffienna were significantly higher than those exposed to the lowest experimental dosage $(1.0 \mathrm{~g} / 20 \mathrm{~g}$ of paddy rice) after 24,48 and 96 hours post-treatment respectively (Table 2 ). But, no significant difference $(p>0.05)$ existed in the mortality of moths exposed to all the experimental dosage of $A$. godseffienna after 72 hours post-treatment (Table 2). No mortality was recorded in the control.

\section{Lethal dose ( $L D_{50}$ and $\left.\mathrm{LD}_{95}\right)(\mathrm{g} / 20 \mathrm{~g}$ of rice)} of $A$. boonei and $A$. goseffiana against $S$. cerealella infesting rice grains

Table 3 shows the lethal dose of both botanical powders required to achieve 50\% and 95\% mortality in $S$. cerealella infesting rice grains after 24 and 72 hours post-treatment. Positive slope of regression irrespective of the duration and botanical powder shows that moth mortality increased with increasing dosage of both botanicals. Lethal doses $\left(\mathrm{LD}_{50}\right.$ and $\left.\mathrm{LD}_{95}\right)$ of each botanical however decreased with increasing exposure time. Lower dosage of $A$. boonei was however required to achieve $50 \%$ (24 hours: $0.672 ; 72$ hours: 0.006 ) mortality in $S$. cerealella when compared to that of $A$. godseffienna (24 hours: 1.546; 72 hours: $0.238)$. Also, there was significant difference $(p<0.05)$ between the $\mathrm{LD}_{50}$ (after 24 and 72 hours) as well as $\mathrm{LD}_{95}$ (after 24 and 72 hours) values of $A$. boone $i$ as inferred by their fiducial limits. Significant difference $(p<0.05)$ also existed between the $\mathrm{LD}_{50}$ values of $A$. godseffiana after 24 and 72 hours. No significant difference $(p>0.05)$ however existed between the $\mathrm{LD}_{95}$ values of $A$. godseffiana after 24 and 72 hours post-treatment.

Adult emergence and percentage inhibition rate of $S$. cerealella in paddy rice treated with $A$. boone $i$ and $A$. godseffiana powders

The effect of both plant powders on the adult emergence of $S$. cerealella is presented in Figure 1. A. boonei evoked a significant reduction $\left(\mathrm{F}_{5,18}=22.87 ; p<0.0001\right)$ in the emergence of adult $S$. cerealella at all experimental dosages when compared to control while $A$. godseffiana applied at $2 \mathrm{~g}, 3 \mathrm{~g}$, $4 \mathrm{~g}$ and $5 \mathrm{~g} / 20 \mathrm{~g}$ of paddy rice significantly reduced $\left(\mathrm{F}_{5,18}=9.96 ; p<0.0001\right)$ emergence of adult moth when compared to control. Likewise, A. boonei applied at the highest experimental dosage $(5 \mathrm{~g} / 20 \mathrm{~g}$ of paddy rice) significantly reduced $(p<0.05)$ emergence of $S$. cerealella when compared to paddy rice exposed to $1 \mathrm{~g}$ and $2 \mathrm{~g}$ of $A$. boonei respectively. No significant difference $(p>0.05)$ however existed in the adult emergence of paddy rice exposed to $2 \mathrm{~g}, 3 \mathrm{~g}$, $4 \mathrm{~g}$ and $5 \mathrm{~g}$ of $A$. godseffiana respectively. Higher number of moth also emerged from paddy rice treated with $A$. godseffiana when compared to their counterpart exposed to $A$. boonei.

Figure 2 shows that the percentage rate of inhibition in adult emergence of $S$. cerealella reduced with increasing dosage of both powders of $A$. boonie and $A$. godseffiana. There was however a significant effect of $A$. boonei $\left(\mathrm{F}_{4,15}=6.69 ; \mathrm{P}=0.003\right)$ on the percentage inhibition rate of $S$. cerealella. However, the effect of $A$. godseffiana on the inhibition rate of $S$. cerealella was not significant $\left(\mathrm{F}_{4,15}=1.65\right.$; $\mathrm{P}=0.213$ ). A. boonei applied at the highest experimental dosage $(5 \mathrm{~g} / 20 \mathrm{~g}$ of paddy rice) significantly inhibited emergence of $S$. 
cerealella in paddy rice when compared to inhibition rate in paddy rice treated with $1 \mathrm{~g}$ and $2 \mathrm{~g}$ of $A$. boonei respectively. But, neither of the two botanical powders elicited complete inhibition in adult emergence of $S$. cerealella at all the experimental dosage.

Table 1: Percentage mortality of $S$. cerealella exposed to A. boonei powder

\begin{tabular}{lllll}
\hline \multirow{2}{*}{$\begin{array}{l}\text { Dosage }(\mathrm{g} / 20 \mathrm{~g} \text { of } \\
\text { rice) }\end{array}$} & \multicolumn{4}{c}{ Exposure time (Hours) } \\
\cline { 2 - 5 } & 24 & 48 & 72 & 96 \\
\hline Control & $0.00 \pm 0.00^{\mathrm{a}}$ & $0.00 \pm 0.00^{\mathrm{a}}$ & $0.00 \pm 0.00^{\mathrm{a}}$ & $0.00 \pm 0.0^{\mathrm{a}}$ \\
1.0 & $57.50 \pm 2.50^{\mathrm{b}}$ & $75.00 \pm 2.89^{\mathrm{b}}$ & $87.65 \pm 9.32^{\mathrm{b}}$ & $92.90 \pm 4.44^{\mathrm{b}}$ \\
2.0 & $62.50 \pm 2.50^{\mathrm{bc}}$ & $77.50 \pm 2.50^{\mathrm{b}}$ & $87.73 \pm 2.53^{\mathrm{b}}$ & $95.40 \pm 4.60^{\mathrm{b}}$ \\
3.0 & $65.00 \pm 2.89^{\mathrm{bcd}}$ & $77.50 \pm 8.54^{\mathrm{b}}$ & $87.68 \pm 6.13^{\mathrm{b}}$ & $96.15 \pm 3.85^{\mathrm{b}}$ \\
4.0 & $75.00 \pm 5.00^{\text {cd }}$ & $90.00 \pm 7.07^{\mathrm{b}}$ & $90.20 \pm 5.66^{\mathrm{b}}$ & $97.15 \pm 2.85^{\mathrm{b}}$ \\
5.0 & $76.75 \pm 1.97^{\mathrm{d}}$ & $92.50 \pm 4.79^{\mathrm{b}}$ & $95.40 \pm 4.60^{\mathrm{b}}$ & $97.73 \pm 2.28^{\mathrm{b}}$ \\
\hline
\end{tabular}

Mean \pm SE values followed by the same superscript letter (s) down the column are not significantly different $(\mathrm{P}>0.05)$ using Turkey's Test.

Table 2: Percentage mortality of $S$. cerealella exposed to A. godseffiana powder

\begin{tabular}{lllll}
\hline Dosage $(\mathrm{g} / 20 \mathrm{~g}$ of rice) & \multicolumn{4}{c}{ Exposure time (Hours) } \\
\cline { 2 - 5 } & 24 & 48 & 72 & 96 \\
\hline Control & $0.00 \pm 0.00^{\mathrm{a}}$ & $0.00 \pm 0.00^{\mathrm{a}}$ & $0.00 \pm 0.00^{\mathrm{a}}$ & $0.00 \pm 0.0^{\mathrm{a}}$ \\
1.0 & $45.00 \pm 2.89^{\mathrm{b}}$ & $60.00 \pm 4.08^{\mathrm{b}}$ & $72.50 \pm 2.50^{\mathrm{b}}$ & $75.18 \pm 4.94^{\mathrm{b}}$ \\
2.0 & $52.50 \pm 4.79^{\mathrm{bc}}$ & $70.00 \pm 4.08^{\mathrm{bc}}$ & $82.50 \pm 4.79^{\mathrm{b}}$ & $87.70 \pm 2.30^{\mathrm{c}}$ \\
3.0 & $55.00 \pm 5.00^{\mathrm{bc}}$ & $75.00 \pm 2.89^{\mathrm{bcd}}$ & $87.50 \pm 4.79^{\mathrm{b}}$ & $87.70 \pm 2.30^{\mathrm{c}}$ \\
4.0 & $72.50 \pm 6.29^{\mathrm{cd}}$ & $80.00 \pm 7.07^{\mathrm{cd}}$ & $90.00 \pm 4.08^{\mathrm{b}}$ & $93.73 \pm 2.26^{\mathrm{c}}$ \\
5.0 & $85.00 \pm 6.45^{\mathrm{d}}$ & $92.50 \pm 4.79^{\mathrm{d}}$ & $92.50 \pm 4.79^{\mathrm{b}}$ & $95.23 \pm 2.76^{\mathrm{c}}$ \\
\hline
\end{tabular}

Mean \pm SE values followed by the same superscript letter (s) down the column are not significantly different $(\mathrm{P}>0.05)$ using Turkey's Test.

Table 3: Lethal dose $\left(\mathrm{LD}_{50}\right.$ and $\left.\mathrm{LD}_{95}\right)(\mathrm{g} / 20 \mathrm{~g}$ of rice) of $A$. boonei and $A$. goseffiana against $S$. cereallela infesting rice grains

\begin{tabular}{lcllll}
\hline $\begin{array}{l}\text { Botanical (g/20g } \\
\text { of rice) }\end{array}$ & $\begin{array}{c}\text { Exposure time } \\
\text { (Hours) }\end{array}$ & Slope $\pm \mathrm{SE}$ & $\overline{\mathrm{X}}^{2}$ & $\mathrm{LD}_{50}(95 \% \mathrm{FL})$ & $\mathrm{LD}_{95}(95 \% \mathrm{FL})$ \\
\hline Alstonia boonei & 24 & $0.78 \pm 0.12$ & 35.19 & $0.672(0.221-1.064)$ & $87.76(28.83-1537.33)$ \\
& 72 & $0.48 \pm 0.15$ & 241.51 & $0.006(0.000-0.012)$ & $15.135(3.123-27.147)$ \\
Acalypha & 24 & $1.43 \pm 0.12$ & 124.90 & $1.546(0.903-2.041)$ & $22.06(10.739-146.685)$ \\
godseffiana & 72 & $1.053 \pm 0.14$ & 120.81 & $0.238(0.001-0.646)$ & $8.655(4.561-251.695)$ \\
\hline
\end{tabular}

SE: Standard error; $\vec{x}$ : Chi square; LD: Lethal dose; FL: Fiducial limit; Values in parenthesis represents $95 \%$ fiducial limit. 


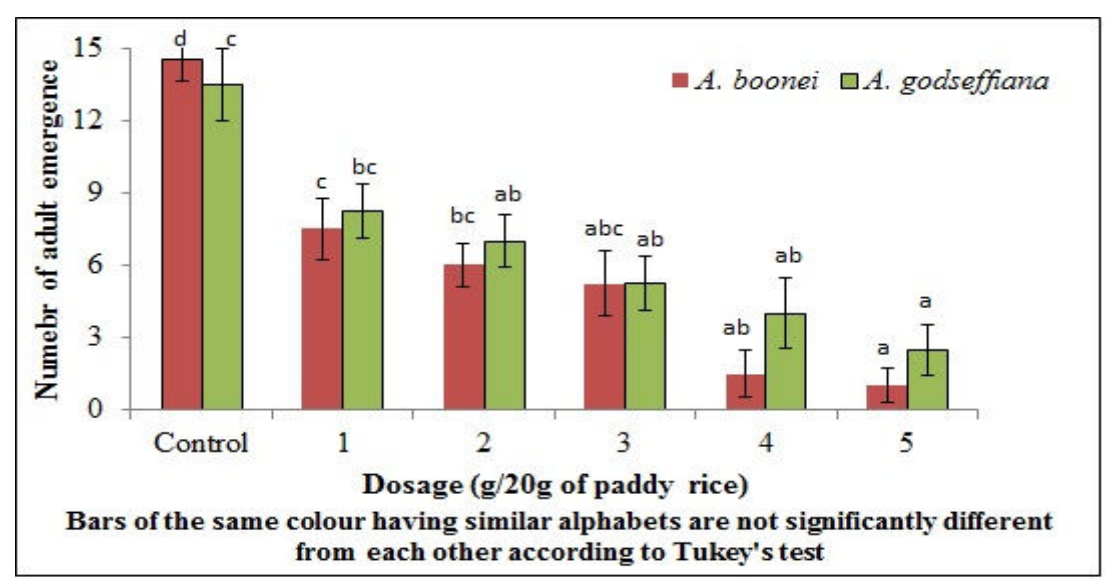

Figure 1: Effect of powders of A. boonei and A. godseffiana on the emergence of S. cerealella infesting paddy rice

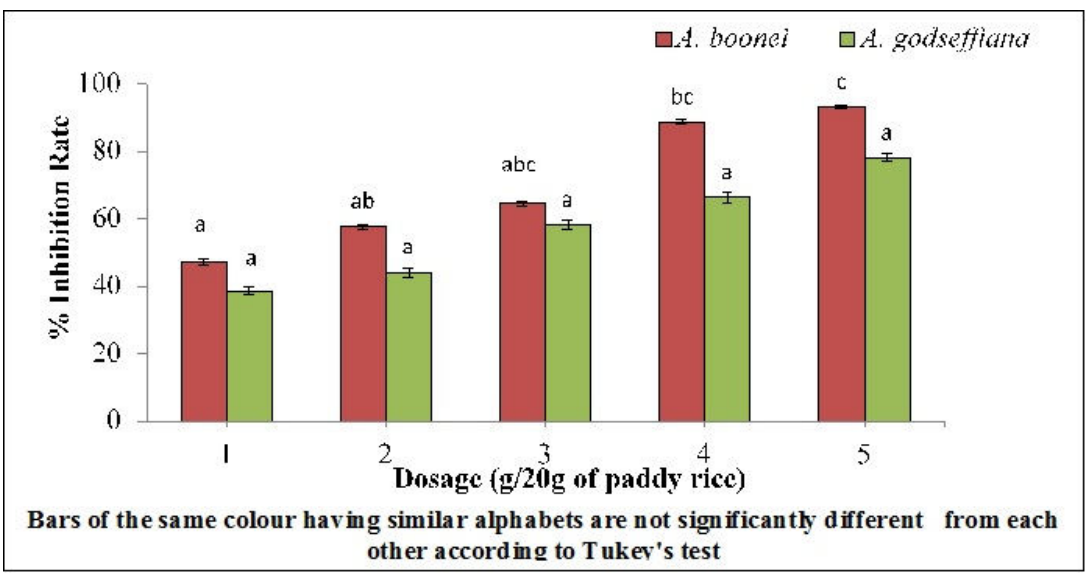

Figure 2: Percentage inhibition rate of $S$. cerealella in paddy rice treated with powders of $A$. boonei and A. godseffiana

\section{DISCUSSION}

The use of plant materials as botanical insecticides is a common and age-long practice in Nigeria and other African countries (Gbaye et al., 2015). Consequently, plant parts of several flora have been investigated for their insecticidal activities against stored product pests and this has helped in reducing losses associated with most of these pests. In this study, the effectiveness of powders of $A$. boonei stem-bark and A. godseffiana leaves as a mothcidal agent was investigated. Both plant powders evoked moth mortality irrespective of the experimental dosage and exposure time. This demonstrates the mothcidal potential of both botanicals against Sitotroga cerealella, thus corroborating similar observation made by Ashamo et al. (2013) and Akinneye and Oyeniyi (2016). However, the effectiveness of both botanical powders against $S$. cerealella varied with their doses and exposure periods.

Lower values of lethal doses $\left(\mathrm{LD}_{50}\right.$ and $\left.\mathrm{LD}_{95}\right)$ of A. Boonie compared to A. godseffiana showed higher toxicity of the former against $S$. Cerealella when compared to the latter. This may be attributed tomoderate to high occurrence of phytochemical compounds in $A$. boonei stem bark when compared to that of $A$. godseffiana (Oyarinde, 2016). For instance, Fashola and Egunyomi (2005), Basu et al. (2007) and Oyarinde (2016) reported higher 
occurrence of saponins, flavonoids and alkaloids in A. boonei than in A. godseffiana. Most of these compounds have been established to be highly insecticidal to several stored product pests (Chaieb, 2010; Kosini and Nukenine, 2017). For instance, Ogungbite and Oyeniyi (2014) as well as Akinneye and Oyeniyi (2016) have earlier linked the insecticidal efficacy of some botanicals to these phytochemical compounds. This may be responsible for higher efficacy of powders of $A$. boonei stem bark when compared to that of $A$. godseffiana leaves.

Also, powders of both botanicals significantly reduced emergence of $S$. cerealella when compared to control. This confirms the possible obvious effect of $A$. boone $i$ and $A$. godseffiana powders on the post embryonic survivalof $S$. cerelealla. This in turn might have significantly reduced adult emergence from treated paddy rice when compared to control. However, the emergence of fewer adults in $A$. boonei treated paddy rice when compared to $A$. godseffiana treated grains may further be ascribed to fewer phytochemical compounds, especially alkaloids in the latter when compared to the former (Oyarinde, 2016). Alkaloids have been generally reported to disrupt insect life cycle by reducing the growth and survival of larva and adult insect respectively (Ogungbite and Oyeniyi, 2014). This work is therefore inagreement with the findings of Ashamo and Akinnawonu (2012), Akinneye and Ogungbite (2013) as well as Ogungbite et al. (2014) where powders of different plant materials successfully prevented eclosion of adult insects. Equally, there was significant effect of $A$. boonei on the percentage inhibition rate of $S$. cerealella. However, the effect of $A$. godseffiana on the inhibition rate of $S$. cerealella was not significant. Neither of the two botanicals elicited complete inhibition in adult emergence of $S$. cerealella at all the experimental dosage. No significant difference also existed in the inhibition rate of $S$. cerealella treated with $A$. godseffiana. The high inhibition in adult emergenceobserved at the highest experimental dosage ( $5.0 \mathrm{~g}$ ) of $A$. boone $i$ when compared to $A$. godseffiana may be ascribed to more chemical compositions, particularly alkaloids in $A$. boonei when compared to $A$. godseffiana. This study has therefore established the potential insecticidal efficacy of powders of $A$. boonei and $A$. godseffiana against $S$. cerealella infesting paddy rice in Nigeria.

\section{REFERENCES}

Abbott, W.S. (1925). A method for computing the effectiveness of an insecticide. Journal of Economical Entomology, 18: 265-267.

Adotey, J.P.K., Adukpo, G.E, Boahen, Y.O. and Armah,F.A. (2012). A review of the enthnobotany and pharmacological importance of Alstonia boonei De Wild (Apocyanaceae): ISRN Pharmacology, Vol. 2012, Article 1D 587160, 1-9.

Akinkurolere, R.O. (2007). Assessment of the insecticidal properties of Anchomanes difformis (P. Beauv.) powder on five beetles of stored produce. Journal of Entomology, 4: 51-55.

Akinneye, J.O. and Ogungbite, O.C. (2013). Insecticidal activities of some medicinal plants against Sitophilus zeamais (Motschulsky) (Coleoptera: Curculionidae) on stored maize. Archives of Phytopathology Plant Protection, 46 (10): 1206-1213.

Akinneye, O.A. and Oyeniyi, E.A. (2016). Insecticidal efficacy of Cleistopholis patens (Benth) powder against Sitotroga cerealella (Olivier) (Lepidoptera: Gelechiidae) infesting rice grains in Nigeria. Journal of Crop Protection, 5(1): 1-10.

Ashamo, M. O. and Akinnawonu, O. (2012). Insecticidal efficacy of some plant powders and extracts against the Angoumois grain moth, Sitotroga cerealella (Olivier) (Lepidoptera: Gelechiidae). Archives of 
Phytopathology and Plant Protection, 45(9): 1051-1058.

Ashamo, M.O, Odeyemi, O.O and Ogungbite, O. C. (2013). Protection of cowpea, Vignaunguiculata L. (Walp.) with Newbouldialaevis (Seem.) extracts against infestation by Callosobruchus maculatus (Fabricius). Archives of Phytopathology of Plant Protection, 46(11): 1295-1306.

Basu, S.K., Thomas, J.E. and Acharya, S.N. (2007). Prospects for Growth in Global Nutraceutical and Functional Food Markets: A Canadian Perspective. Australian Journal of Basic Applied Science, 1(4): 637-649.

Chaieb, I. (2010). Saponins as insecticides: A review. Tunisian Journal of Plant Protection, 5: 39-50.

Fashola, T.R and Egunyomi, A. (2005). Nigerian usage of bark in phytomedicine. Ethnobotany Research and Applications, 3: 73-77.

Finney, D. J. (1971). Probit Analysis. Cambridge University Press, Cambridge, London, 333.

Gbaye, O.A., Oyeniyi, E.A. and Adekanmbi, F. (2015). The efficacy of three plant powders as an entomocide against Sitophilus oryzae (Linnaeus) infesting rice grains in Nigeria. International Journal of Research Studies in Zoology, 1(1): 30-35.

Goronyo, A. (2017). Rice production in Nigeria increases to 5.8 million tonnes in 2017 RIFAN. Retrieved from https://punchng.com/ rice-production-in-nigeria-increases-to-5-8mtonnes-in-2017-rifan/ (Accessed 24th July, 2018).

Jenson, T.G., Palsson, K. and Borg-Karlson, A.K. (2006). Evaluation of extracts and oils of mosquito (Diptera: Culicidae) repellent plants from Sweden and Guinea-Bissau. Journal of Medical Entomology, 43: 113-119.

Kosini, D. and Nukenine, E.N. (2017). Bioactivity of novel botanical insecticide from Gnidia kaussiana (Thymeleaceae) against Callosobruchus maculatus (Coleoptera: Chrysomelidae) in stored Vigna subterranea
(Fabaceae) grains. Journal of Insect Science, 17(1): 1-7.

Ogundaini, A.O. (2005). From Greens into medicine. Taking a lead from nature. An inaugural Lecture Delivered at Oduduwa Hall, Obafemi Awolowo, University, Ile-Ife, Nigeria Inaugural Lectures Series 176. OAU. Press Limited. Ile-Ife Nigeria, 12-15.

Ogungbite, O.C. and Oyeniyi, E.A. (2014). Newbouldia laevis (Seem) as an entomocide against Sitophilus oryzae and Sitophilus zeamais infesting maize grain. Jordan Journal of Biological Science, 7(1): 49-55.

Ogungbite, O.C., Odeyemi, O.O. and Ashamo M.O. (2014). Powders of Newbouldia laevis as protectants of cowpea seeds against infestation by Callosobruchus maculatus (Fab.) for poor resource farmers. Octa Journal of Biosciences, 2(1): 40-48.

Oladimeji, Y.U. (2017). Food production trend in Nigeria and Malthus theory of population: empirical evidence from rice production. Nigerian Journal of Agriculture, Food and Environment, 13(1): 126-132.

Oyarinde, A.J. (2016). Bioactivity of two botanical extracts against Sitophilus oryzae (Linnaeus) and Sitophilus zeamais (Motschulsky) infesting wheat grains. B. Tech Dissertation, Federal University of Technology Akure, Nigeria, 47pp.

Phillips, T.W. and Throne, J.E. (2010). Biorational approaches to managing storedproduct insects. Annual Review of Entomology, 55: 375-397.

Tapondju, I.A., Alder, A., Fontem, H. and Fontem, D. A. (2002). Efficacy of powder and essential oil from Chenopodium ambrosioides leaves as post-harvest grain protectants against six stored products beetles. Journal of Stored Products Research, 38: 395-402.

Togola, A., Seck, P. A., Glitho, I. A., Diagne, A., Adda, C., Toure, A. and Nwilene, F. E. (2013). Economic losses from insect pest 
infestation on rice stored on-farm in Benin.

Journal of Applied Science, 13 (2): 278285.

Vaughan, I.O., Afolami, C.A., Oyekale, T.O. and
Ayegbokiki, A. O. (2014). An analysis of Nigeria food imports and bills. International Journal of Economics, Commerce and Management, 2(9): 1-14.

Nigeria Journal of Entomology

Published by the Entomological Society of Nigeria

www.esnjournal.com.ng

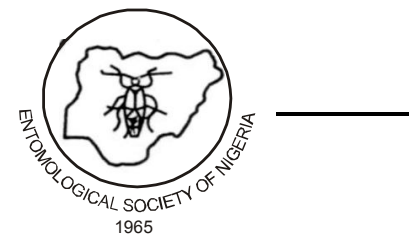

ISSN: 0331-0094

Vol. 34, 2018; pp. 9-17

DOI: $10.36108 / \mathrm{NJE} / 8102 / 43(0120)$ 